\title{
Education scholarship in emergency medicine part 1: innovating and improving teaching and learning
}

\author{
Jonathan Sherbino, MD, MEd*; Elaine van Melle, $\mathrm{PhD}^{\dagger}$; Glen Bandiera, MD, MEd ${ }^{\ddagger}$; \\ Jill McEwen, $\mathrm{MD}^{\S}$; Constance LeBlanc, MD, MA(Ed)"; Farhan Bhanji, MD, MSc(HPE) ${ }^{\mp}$; \\ Jason R. Frank, MD, MA(Ed) ${ }^{\#}$; Glenn Regehr, PhD**; Linda Snell, MD, MHPE*
}

\begin{abstract}
As emergency medicine (EM) education evolves, a more advanced understanding of education scholarship is required. This article is the first in a series of three articles that reports the recommendations of the 2013 education scholarship consensus conference of the Academic Section of the Canadian Association of Emergency Physicians. Adopting the Canadian Association for Medical Education's definition, education scholarship (including both research and innovation) is defined. A rationale for why education scholarship should be a priority for EM is discussed.
\end{abstract}

\section{RÉSUMÉ}

À mesure qu'évolue l'éducation en médecine d'urgence (MU), une compréhension approfondie des bourses d'études en éducation s'impose. II s'agit du premier article d'une série de trois, qui fait état des recommandations issues de la conférence de consensus de 2013 sur les bourses d'études en éducation, tenue par la division Academic de l'Association canadienne des médecins d'urgence. Après adoption du terme selon I'Association canadienne pour l'éducation médicale, il y a eu définition de l'expression bourse d'études en éducation (s'appliquant tant à la recherche qu'à l'innovation). Suivra un exposé des motifs pour lesquels les bourses d'études en enseignement devraient être une priorité en MU.

Keywords: education scholarship, innovation, research

Work that is valued is work that is presented to colleagues. The failure to make this kind of wider connection weakens the sense of community. ${ }^{1}$
Education in emergency medicine (EM) is evolving rapidly with the development of new approaches to learning, such as simulation ${ }^{2}$ and competency-based medical education. ${ }^{3}$ In parallel (and perhaps as a response) to these transforming influences, the concept of education scholarship is emerging in EM education. ${ }^{4}$ Originally advanced by Boyer, ${ }^{5}$ education scholarship marries scholarly inquiry to any of the intellectual tasks that comprise the education process: designing a curriculum, establishing learning objectives, facilitating learning activities, assessing outcomes, or evaluating programs. ${ }^{6}$

This paper begins by defining education scholarship. It then offers a rationale for positioning EM as a leader in education scholarship. Finally, recommendations ensuing from the first consensus conference of the Academic Section of the Canadian Association of Emergency Physicians (CAEP) are presented. We propose that the implementation of these recommendations and the recommendations from the two companion papers (also in this issue of $C \mathcal{E} E M^{7,8}$ ) will not only increase EM education scholarship but will ultimately lead to enhancement of the quality of EM education. ${ }^{9}$

\section{WHAT IS EDUCATION SCHOLARSHIP?}

In an age when traditional research activities (e.g., grants, publications) are a potent currency in our

From the *Division of Emergency Medicine, McMaster University, Hamilton, ON; †Department of Family Medicine, Queen's University, Kingston, ON; ‡Department of Medicine, University of Toronto, Toronto, ON; §Department of Emergency Medicine, University of British Columbia, Vancouver, BC; ॥Department of Emergency Medicine, Dalhousie University, Halifax, NS; ๆCentre for Medical Education, McGill University, Montreal, QC; \#Department of Emergency Medicine, University of Ottawa, Ottawa, ON; and ${ }^{* *}$ Centre for Health Education Scholarship, University of British Columbia, Vancouver, $\mathrm{BC}$.

Correspondence to: Dr. Jonathan Sherbino, McMaster Clinic, Hamilton General Hospital, 237 Barton Street East, Hamilton, ON L8L 2X2; sherbino@ mcmaster.ca.

This article has been peer reviewed. 
academic institutions, it is essential for the ongoing support and advancement of EM educators and programs that we articulate both a definition of education scholarship and its value. The EM literature has attempted to define education scholarship ${ }^{10-13}$ and related core areas: theory of teaching and learning, research methods, and education administration., ${ }^{9,14,15}$ The differing perspectives suggest that further clarification may be valuable.

Building on the early work of Boyer, ${ }^{5}$ who first articulated an expanded construction of scholarship, and borrowing concepts from Schulman's pioneering work for the Carnegie Foundation, ${ }^{6}$ the Canadian Association for Medical Education's recent position paper has provided a clear definition: "Education Scholarship is an umbrella term which can encompass both research and innovation in health professions education. Quality in education scholarship is attained through work that is: peer-reviewed, publicly disseminated and provides a platform that others can build on." ${ }_{16}$ This definition is echoed in other medical education publications ${ }^{17-22}$ and is now broadly understood to include both research (basic, applied) and innovation (design, implementation, and evaluation). ${ }^{16}$ For example, basic education research includes determining how emergency physicians arrive at a diagnosis, ${ }^{23}$ whereas applied education research might determine the qualities of effective EM teachers. ${ }^{24}$ By comparison, education innovations could include the design of an EM clerkship, ${ }^{25}$ the implementation of a novel EM rotation, ${ }^{26}$ or the evaluation of EM simulation technology. ${ }^{2}$

Glassick offered six criteria for judging academic work as scholarly: clear goals (i.e., an important idea); adequate preparation (i.e., work built on existing scholarship); appropriate methods, significant results, and effective presentation (i.e., dissemination); and reflective critique (i.e., evaluation of the innovation). ${ }^{27}$ These criteria permitted greater clarity in distinguishing between scholarly teaching and the scholarship of teaching that had confused Boyer's original work. A teacher who applies theory and best practices to improve the educational experience of the learner is engaging in scholarly teaching. ${ }^{28}$ In contrast, the scholarship of teaching involves a distinct innovation that builds on previous work, is communicated widely to permit critique and subsequent refinement, and ultimately advances the field of education. Scholarly teaching is "evidence-based" teaching, whereas the scholarship of teaching produces the "evidence." 20

The CanMEDS/CanMEDS-FM framework ${ }^{29,30}$ defines competent practice for all physicians in Canada. The framework includes the Scholar role, which involves the "creation, dissemination, application, and translation" 29 of knowledge. Not everyone in the EM community is required to be an education scholar; everyone is positioned to support the advancement of EM education via our direct or indirect participation in scholarly activities. Yet, as EM teachers and educators, we all need to ensure that our teaching applies and translates the best education knowledge.

\section{WHY SHOULD EDUCATION SCHOLARSHIP BE A PRIORITY} FOR EM?

EM is increasingly recognized as a leader in undergraduate and postgraduate medical education and in other health professions (i.e., nurses, paramedics, physician assistants) education. Prior to becoming a specialty in Canada in 1980, , $^{31,32}$ teaching in an emergency department was ad hoc at best. Today, 14 of 17 Canadian medical schools have mandatory EM clerkships. In addition, there are 14 Royal College EM specialist residency programs ${ }^{33}$ and 17 College of Family Physicians of Canada special competency in EM programs. ${ }^{34}$ The scope of undifferentiated clinical experiences and the tailored, experiential learning that stems from immediate, direct feedback from faculty makes the emergency department a highly effective education venue. This unique learning environment has the potential for significant influence given that (nearly) every Canadian physician completes an EM rotation during his or her training. This EM teaching potentially translates to an equally significant impact on education systems. In addition, the EM community is nationally connected and involved in issues relating to clinical care, systems administration, and clinical research.

Despite the strengths of EM education, related scholarship requires increased support. The Academic Section of the CAEP held a consensus conference on education scholarship because 1) Canadian EM education scholarly activity is modest; 2) national EM networks are ad hoc and inconsistent; 3) academic EM organizations (e.g., university departments, the CAEP) provide only a small amount of support for both education scholars and for developing the next generation of scholars; and 4) the EM community is 
generally unfamiliar with the updated definition of education scholarship, which prevents broad-based endorsement and contributions to education scholarship. Yet the strengths of the EM education system, as articulated above, situate our specialty to be a frontrunner in education scholarship.

Supporting education scholarship will serve the needs of the EM community in three key ways. First, although EM is an internally well-connected specialty, its impact on Canadian academic organizations remains modest when compared to surgical and medical specialties. Adopting a common definition and taxonomy of education scholarship and supporting local efforts will allow the EM community to link valuable "education laboratories" (i.e., emergency departments) across the country. The resulting coordinated and expanded education scholarship will lead to influence and impact on the academic systems, which, in turn, influence EM.

Second, although some high-quality EM scholarship is being produced, numerous education questions remain, both generally and for EM specifically. ${ }^{35,36}$ Even in areas where education research has clearly identified best practices, wide-scale adoption remains limited, suggesting the need for scholarship that addresses implementation. ${ }^{37}$ Enhancing the profile of education scholarship will ensure an ongoing commitment to high-quality, best evidence EM education. Ultimately, EM education scholarship holds the promise of improving the care of our patients; however, the challenge of demonstrating causality remains. ${ }^{38}$

Finally, for EM faculty members and trainees, promoting education scholarship may promote EM as a specialty choice and stimulate the development of the next generation of EM educators. As the specialty of EM grows, a proportional number of teachers, educators, and scholars is required. Building capacity will be key to sustaining a healthy education environment. The recognition of education scholarship by the EM community may facilitate subsequent recognition by academic organizations. This acknowledgement would lead to the appropriate support of EM education scholars that currently exists for other academic pathways (e.g., clinician-scientist programs).

In June 2013, the Academic Section of the CAEP hosted a consensus conference on education scholarship as part of the CAEP's annual national meeting in Vancouver, British Columbia. Through a process that included a review of the literature, expert thematic analysis, and iterative consensus agreement, a common definition of education scholarship was agreed upon by the more than 80 participants in attendance.

Two companion papers in this issue of CFEM address additional, related themes: processes and strategies to produce education scholarship; and the necessary institutional support of education scholarship. ${ }^{7,8}$ A series of recommendations accompanies each paper.

\section{RECOMMENDATIONS}

Based on the proceedings of the first consensus conference of the Academic Section of the CAEP, the following recommendations were unanimously endorsed:

\section{DEFINING AND PROMOTING EM EDUCATION SCHOLARSHIP}

1. The Academic Section should adopt the Canadian Association for Medical Education's definition of education scholarship for use in Emergency Medicine.

The key elements of education scholarship under this definition are that it:

- consists of education research (basic, applied or inquiry based) or education innovations (design, implementation or evaluation);

- is built on previous theory, principles or best practices;

- is reviewed by peers; assessed based on impact;

- is publicly disseminated and archived for critique; and to advance the field.

2. The Academic Section should promote EM teaching that is informed by education scholarship.

a. Action Item: Academic divisions/departments of EM should provide faculty development to EM teachers to assist in the implementation of scholarly teaching (i.e. best teaching practices).

b. Action Item: Academic divisions/departments of EM should support interested EM teachers and educators in developing 
scholarly innovations and augmenting these into education scholarship.

\section{CONCLUSION}

The first consensus conference of the Academic Section of the CAEP adopted a common definition of education scholarship and proposed that EM teaching be informed by theory and best practice. The Canadian EM community is positioned to be a leader in education if it can support both EM teachers in adopting best practices and EM scholars in developing education innovations.

Acknowledgements: We wish to acknowledge the participation of the consensus conference attendees and the CAEP Education Scholarship Working Group.

Competing interests: None declared.

\section{REFERENCES}

1. Glassick CE. Scholarship assessed: evaluation of the professoriate [Special Report (Carnegie Foundation for the Advancement of Teaching)]. San Francisco (CA): Jossey-Bass; 1997.

2. Ilgen JS, Sherbino J, Cook DA. Technology-enhanced simulation in emergency medicine: a systematic review and meta-analysis. Acad Emerg Med 2013;20:117-27, doi:10.1111/ acem.12076.

3. Frank JR, Snell LS, Cate OT, et al. Competency-based medical education: theory to practice. Med Teach 2010;32: 638-45, doi:10.3109/0142159X.2010.501190.

4. Sherbino J. Education scholarship: the next step for our specialty. CFEM 2010;12:347-8.

5. Boyer EL. Scholarship reconsidered: priorities for the professoriate. Princeton (NJ): The Carnegie Foundation for the Advancement of Teaching; 1990.

6. Shulman L. The scholarship of teaching. Change 1999; 31(5):11.

7. Bandiera G, LeBlanc C, Regehr G, et al. Education scholarship in emergency medicine part 2: supporting and developing scholars. CFEM 2014;16:00-00.

8. Bhanji F, Cheng A, Frank J, et al. Education scholarship in emergency medicine part 3: a "how-to" guide. CFEM 2014; 16:00-00.

9. Coates WC, Lin M, Clarke S, et al. Defining a core curriculum for education scholarship fellowships in emergency medicine. Acad Emerg Med 2012;19:1411-8, doi:10.1111/acem.12036.

10. Schrader C, Barsan WG, Gordon JA, et al. Scholarship in emergency medicine in an environment of increasing clinical demand: proceedings from the 2007 Association of American Medical Colleges annual meeting. Acad Emerg Med 2008;15: 567-72, doi:10.1111/j.1553-2712.2008.00118.x.
11. Yarris LM, Deiorio NM. Education research: a primer for educators in emergency medicine. Acad Emerg Med 2011;18 Suppl 2:S27-35, doi:10.1111/j.1553-2712.2011.01189.x.

12. Lamantia J, Kuhn GJ, Searle NS. The CORD Academy for scholarship in education in emergency medicine. Acad Emerg Med 2010;17 Suppl 2:S13-5, doi:10.1111/j.1553-2712.2010. 00895.x.

13. Love JN, Coates WC, Santen SA, et al. The MERC at CORD Scholars Program in medical education research: a novel faculty development opportunity for emergency physicians. Acad Emerg Med 2009;16 Suppl 2:S37-41, doi:10.1111/j.1553-2712.2009.00591.x.

14. Yarris LM, Coates WC, Lin M, et al. A suggested core content for education scholarship fellowships in emergency medicine. Acad Emerg Med 2012;19:1425-33, doi:10.1111/ acem.12032.

15. Lin M, Santen SA, Yarris LM, et al. Development of a training needs assessment for an education scholarship fellowship in emergency medicine. Acad Emerg Med 2012; 19:1419-24, doi:10.1111/acem.12035.

16. van Melle E, Curran V, Goldszmidt M, et al, Toward a common understanding: advancing education scholarship for clinical faculty in Canadian medical schools. A position paper. Ottawa: Canadian Association for Medical Education; 2012.

17. Fincher RE, Work JA. Perspectives on the scholarship of teaching. Med Educ 2006;40:293-5, doi:10.1111/j.13652929.2006.02404.x.

18. Association of American Medical Colleges. Educational scholarship guides. 2009. Available at: http://www.mededportal.org (accessed October 15, 2013).

19. Regehr G. It's NOT rocket science: rethinking our metaphors for research in health professions education. Med Educ 2010; 44:31-9, doi:10.1111/j.1365-2923.2009.03418.x.

20. Steinert Y, Snell L. Educational innovation and scholarship: from curriculum design to implementation. In: Sherbino J, Frank JR, editors. Educational design: a CanMEDS guide for the health professions. Ottawa: Royal College of Physicians and Surgeons; 2011. p. 81-6.

21. Dolmans DHJM, Tigelaar D. Building bridges between theory and practice in medical education using a designbased research approach: AMEE guide no. 60. Med Teach 2012;34:1-10, doi:10.3109/0142159X.2011.595437.

22. Royal College of Physicians and Surgeons of Canada. The International Clinician Educators Network. Available at: http:// www.royalcollege.ca/portal/page/portal/rc/resources/ice/ definitions (accessed October 15, 2013).

23. Sherbino J, Dore KL, Wood TJ, et al. The relationship between response time and diagnostic accuracy. Acad Med 2012;87:785-91, doi:10.1097/ACM.0b013e318253acbd.

24. Bandiera G, Lee S, Tiberius R. Creating effective learning in today's emergency departments: how accomplished teachers get it done. Ann Emerg Med 2005;45:253-61, doi:10.1016/ j.annemergmed.2004.08.007.

25. Penciner R, Woods RA, McEwen J, et al. Core competencies for emergency medicine clerkships: results of a Canadian consensus initiative. CFEM 2013;15:24-33.

26. Abu-Laban RB, Jarvis-Selinger S, Newton L, et al. Implementation and evaluation of a novel research education rotation for Royal College of Physicians and Surgeons emergency medicine residents. CFEM 2013;15:233-6. 
27. Glassick CE. Boyer's expanded definitions of scholarship, the standards for assessing scholarship, and the elusiveness of the scholarship of teaching. Acad Med 2000;75:877-80, doi:10.1097/00001888-200009000-00007.

28. Hutchings P, Huber MT, Ciccone A. Scholarship of teaching and learning reconsidered: institutional integration and impact. Princeton (NJ): Carnegie Foundation for the Advancement of Teaching; 2011.

29. Frank JR, editor. The CanMEDS 2005 physician competency framework. Better standards. Better physicians. Better care. Ottawa: The Royal College of Physicians and Surgeons of Canada; 2005.

30. The College of Family Physicians of Canada. CanMEDSFamily Medicine: a framework of competencies in family medicine. Available at: http://www.cfpc.ca/ProjectAssets/Templates/ Resource. aspx? id=3031 (accessed October 15, 2013).

31. Johnson R. The Canadian Association of Emergency Physicians. 7 Emerg Med 1993;11:362-4.

32. Walker DMC. History and development of the Royal College Specialty of Emergency Medicine. Ann R Coll Phys Surg Can 1987;20:349-52.
33. The Royal College of Physicians and Surgeons of Canada. Available at: http://www.royalcollege.ca/portal/page/portal/ $\mathrm{rc} /$ credentials/accreditation/arps/specialty/emergency (accessed October 15, 2013).

34. The College of Family Physicians of Canada. University programs. Available at: http://www.cfpc.ca/University_Programs/ (accessed October 15, 2013).

35. Shayne P, Coates WC, Farrell SE, et al. Critical appraisal of emergency medicine educational research: the best publications of 2010. Acad Emerg Med 2011;18:1081-9, doi:10.1111/ j.1553-2712.2011.01191.x.

36. LaMantia J, Hamstra SJ, Martin DR, et al. Faculty development in medical education research. Acad Emerg Med 2012;19:1462-7, doi:10.1111/acem.12037.

37. Santen SA, Deiorio NM, Gruppen LD. Medical education research in the context of translational science. Acad Emerg Med 2012;19:1323-7, doi:10.1111/acem.12040.

38. Cook DA, West CP. Perspective: Reconsidering the focus on "outcomes research" in medical education: a cautionary note. Acad Med 2013;88:162-7, doi:10.1097/ACM.0b013e31827c3d78. 